\title{
Lectio divina: un modo antiguo y actual de orar con la Sagrada Escritura
}

\section{Lectio divina: An Ancient and Current Way of Praying with the Sacred Scripture}

\section{Fernando MiLÁN}

Universidad de Navarra. Facultad de Teología

Pamplona. España

ID ORCID 0000-0000-0000-0000

fmilan@unav.es

Resumen: En este artículo se presenta la lectio divina, una antigua forma de rezar con la Biblia que ha sido redescubierta y revalorizada en nuestros días. Se expondrá qué se entiende hoy por lectio divina y cuáles son sus pasos fundamentales. La descripción de este método -que podría calificarse mejor como un itinerario espiritual en etapas- vendrá precedida de un apunte histórico. Finalmente, se proponen unas pautas prácticas para orientar una posible lectura orante de la Escritura.

Palabras clave: Lectio divina, Lectura orante, Sagrada Escritura hoy, Pastoral bíblica.
Abstract: This article covers lectio divina, an ancient way of praying with the Bible that has recently been rediscovered and better appreciated. It explains the contemporary understanding of lectio divina and its principal steps. The description of this method - which could be identified as a spiritual itinerary in phases- is preceded by a historical note. Finally, some practical measures are offered as guidelines for a prayerful reading of the Scripture.

Keywords: Lectio divina, Prayerful Reading, Sacred Scripture Today, Biblical Pastoral. 


\section{EL REDESCUBRIMIENTO DE LA LECTIO DIVINA}

L a Sagrada Escritura suscita hoy un gran atractivo e interés entre los fieles. No se trata, ciertamente, de una moda más del momento ${ }^{1}$. Es, más bien, resultado del «despertar de la Palabra» que trajo consigo el Concilio Vaticano $\mathrm{II}^{2}$, con el que se dio por finalizado el -así llamado por algunos«exilio de la Palabra de Dios» en la vida de la Iglesia.

En efecto, tras el Concilio, se dio en todos los ámbitos de la vida eclesial (liturgia, teología, pastoral bíblica, etc.) una cierta «"epifanía" de la Palabra de Dios» ${ }^{3}$. En este contexto se produce el sorprendente auge de la lectio divina (= $L D)$, una antigua forma de rezar con la Biblia que ha sido redescubierta y revalorizada en nuestros días, en parte, gracias al reiterado impulso del Magisterio reciente ${ }^{4}$.

Ya san Juan Pablo II invitaba a comenzar el nuevo milenio con una «renovada escucha de la palabra de Dios», concretamente,

«en la antigua y siempre válida tradición de la $L D$, que permite encontrar en el texto bíblico la palabra viva que interpela, orienta y modela la existencia» ${ }^{5}$.

Su sucesor, Benedicto XVI, fue un gran alentador de la $L D$. En su discurso al congreso internacional con motivo del XL aniversario de la Dei Verbum recomendó

«la antigua tradición de la $L D$ : la lectura asidua de la sagrada Escritura acompañada por la oración realiza el coloquio íntimo en el que, leyendo, se escucha a Dios que habla y, orando, se le responde con confiada apertura del corazón (cfr. $D V 25) \gg^{6}$.

${ }^{1}$ Cfr. Calduch, N., Saboreando la Palabra. Sobre la lectura orante o creyente (lectio divina), Estella: Verbo Divino, 2012, 29; y RaGUER, H., «Introducción a la lectio divina», Cuestiones Teológicas 78 (2005) 366.

${ }^{2}$ La Dei Verbum, en su epílogo, auspiciaba el inicio de «un nuevo impulso de la vida espiritual» gracias a la renovada y creciente «veneración de la palabra de Dios» (CONCILIO VATICANO II, Constitución Dogmática Dei Verbum, n. 26).

3 Bianchi, E., Orar la Palabra, Burgos: Monasterio de las Huelgas, 1994, 21. No es posible detenerse ahora en los factores que contribuyeron a este despertar de la Palabra en el s. XX: cfr. BALaguer, V., «La Constitución Dogmática Dei Verbum y los estudios bíblicos en el siglo XX», Anuario de Historia de la Iglesia 10 (2001) 239-251.

${ }^{4}$ Cfr. Pennington, B., Lectio Divina: Renewing the Ancient Practice of Praying the Scriptures, New York: Crossroad Classic, 1998.

5 Juan Pablo II, Novo Millennio ineunte, n. 39.

${ }^{6}$ Benedicto XVI, Discurso al Congreso Internacional «La Sagrada Escritura en la vida de la Iglesia»: AAS 97/10 (2005) 957. También se refirió a la $L D$ en la Verbum Domini, a la que dedicó dos extensos números (86-87). 
Francisco también se ha referido a la $L D$ y la ha recomendado en distintas ocasiones ${ }^{7}$. En la Evangelii Gaudium, se refiere a ella como

«una forma concreta de escuchar lo que el Señor nos quiere decir en su Palabra y de dejarnos transformar por el Espíritu. Consiste en la lectura de la Palabra de Dios en un momento de oración para permitirle que nos ilumine y nos renueve» ${ }^{8}$.

El impulso dado por los últimos Romanos Pontífices tiene, en cierto modo, como trasfondo la intención de superar el consabido debate entre lectura científica y lectura teológica (espiritual o creyente) de la Biblia, es decir, entre lo que se denominó como «exégesis en la Sorbona» y «exégesis en la Iglesia»?

Esta antigua polémica en torno al «dualismo entre exégesis y teología» ${ }^{10}$ estuvo especialmente presente en la Asamblea sinodal de 2008 y fue lo que motivó la intervención personal de Benedicto XVI, quien pidió estudiar el modo de tener presentes en la exégesis los dos niveles metodológicos, a saber, el histórico-crítico y el teológico. En su intervención, el Papa subrayó que «la creación de una profunda brecha entre exégesis científica y $L D \gg$ se debía precisamente a la ausencia del segundo nivel metodológico, el teológico. Recordó que ya la Dei Verbum ofrecía «dos indicaciones metodológicas para un adecuado trabajo exegético»: el método histórico-crítico y el teológico. Así, advirtió que, mientras se trabajó -y se sigue trabajando- con altísimo rigor en el primer nivel, en cambio el segundo, el que reúne los tres elementos teológicos del n. 12 de Dei Verbum, «casi no existe». Y -concluía- «esto tiene consecuencias bastante graves» ${ }^{11}$. Entre ellas, destacaba el hecho de que el texto sagrado, en ese caso, se quedaba solo como un libro del pasado.

No es momento ahora de exponer cómo se resolvió la petición de Benedicto XVI ${ }^{12}$. Sí puede señalarse, en cambio, que la apuesta del Sínodo por la

${ }^{7}$ Cfr. Audiencia a los seminaristas de Lombardía (Italia): L'Osservatore Romano, ed. italiana (17 ottobre 2018), 4-5.

8 Francisco, Exhortación Apostólica Evangelii Gaudium (24 de noviembre de 2013), n. 152.

9 Cfr. Dreyfus, F., «Exégése en Sorbonne, exégése en Église», Revue Biblique 82 (1975) 321-359: en español puede encontrarse en Granados C. y GimÉnEZ A. (eds.), Biblia y ciencia de la fe, Madrid: Encuentro, 2007, 67-113.

10 BenedICTO XVI, Intervención durante la XIV Congregación General del Sínodo de los obispos: L'Osservatore Romano, ed. en lengua española (24 octubre 2008), 8; cfr. Propositio 25. Su intervención quedará recogida sustancialmente en los nn. 34 y 35 de Verbum Domini.

${ }^{11}$ Ibid.

${ }^{12}$ El propio Pontífice en la Misa conclusiva del Sínodo afirmaba que ambas eran compatibles: «La exégesis científica y la $L D$ son, por tanto, necesarias y complementarias para buscar, a través del sig- 
$L D^{13}$ facilitaba un mayor conocimiento de la Escritura, a la vez que posibilitaba su actualización en la vida de cualquier cristiano ${ }^{14}$.

\section{2. ¿QUÉ ES LA LECTIO DIVINA?}

Aunque a primera vista parezca una tarea sencilla, la verdad es que no resulta fácil definir la $L D$, entre otras cosas, porque se trata de un concepto que puede designar realidades diferentes ${ }^{15}$. A ello se añade su cambiante significado a lo largo de la historia. De ahí que no hayan faltado autores que, al estudiar la $L D$-y en los últimos años ha habido una auténtica oleada de publicaciones ${ }^{16}$-, han diferenciado entre cómo se concebía en el pasado -especialmente en las épocas patrística y medieval- y el significado que ha adquirido más recientemente en nuestros días ${ }^{17}$. Por tanto, si se quiere comprender la naturaleza de la $L D$ es preciso delimitar los términos de la expresión y presentar -aunque solo sea mediante unas breves pinceladas- la historia de su nacimiento y su desarrollo posterior. Comencemos por la etimología.

\subsection{Theía anágnosis: Lectio divina}

Prácticamente desconocida hasta la segunda mitad del s. XX, salvo en ámbito monástico y en el de los especialistas, la expresión lectio divina es ya hoy

nificado literal, el espiritual, que Dios quiere comunicarnos hoy»: L'Osservatore Romano, edición en lengua española (31 de octubre de 2008). Cfr. también VANNI, U., «Exégesis científica y lectio divina: dos realidades inseparables», en García Serrano, A. y Sánchez Navarro, L. (eds.), Dichosos los que escuchan la Palabra. Exégesis biblica y lectio divina, Madrid: Universidad San Dámaso, 2012, 30.

13 Sobre el interés suscitado por la $L D$ en el Sínodo, cfr. CaLduch, N., Saboreando la Palabra, 9-14; CAlduch, N., «El Sínodo de Obispos sobre la Palabra de Dios: balance y perspectivas», Isidorianum 35 (2009) 317-338; y MANICARDI, E., «Verbum Domini: perspectivas teológicas actuales», ScrTh 43 (2011) 393-416, quien subraya que la Verbum Domini, frente a los distintos métodos de lectura orante que se proponían en los documentos preparatorios, elaboró «cuidadosamente una propuesta de específica $L D$. Nunca el Magisterio había sido tan rico y detallado al respecto» (406).

14 En el relanzamiento de la $L D$ suele destacarse también el importante papel, en la década de los 70 del siglo pasado, de Enzo Bianchi: cfr. DREUILLE, C. DE, Lectio divina: un camino para orar la Palabra de Dios, Estella: Verbo Divino, 2014, 30-31. También cabe mencionar a M. Magrassi, quien publicó su guía para la $L D$ poco antes que la de Bianchi: Bibblia e preghiera. Lectio divina, Milano: Àncora, 1973.

15 Puede confundirse, por un lado, con la lectura espiritual, una de las llamadas «variantes» de la LD (cfr. MASINI, M., La lectio divina, 209-236). Por otro lado, la connotación académica del término lectio también podría aludir a las lecciones o clases en la universidad.

${ }^{16}$ Cfr. la bibliografía señalada al final del artículo. Al proponer la $L D$ hoy cada autor lo hace desde un enfoque determinado: litúrgico, patrístico, monástico o pastoral: cfr. MARTín FERNÁNDEZGallardo, A. M., La lectio divina ayer y hoy. Principios y desarrollo histórico, Estella: Verbo Divino, 2012.

${ }^{17}$ Cfr. Maroto, D. de P., «La Lectio divina, praxis histórica y pastoral», Salmanticensis 49 (2002) 433-462. 
una fórmula consagrada y reconocida por todos. Quizás sea menos sabido que la primera vez que se formuló esta expresión no fue en latín sino en griego. Se le debe a Orígenes (ca 185-253), a quien muchos consideran el padre de la $L D$. En una carta a su discípulo Gregorio el Taumaturgo, le alentaba a poner un especial cuidado -ahora que se encontraba lejos de su maestro ${ }^{18}$ - en la lectura y el estudio de los libros divinos:

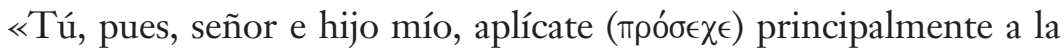

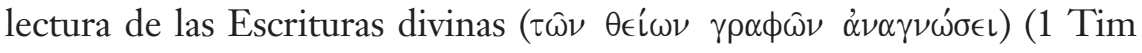
4,13); pero aplícate. Pues de mucha aplicación tenemos necesidad quienes leemos las cosas divinas ( $\tau \alpha \theta \in \hat{\epsilon} \alpha$ ), a fin de no decir ni pensar nada temerariamente acerca de ello. Y al aplicarte en la lectura de las cosas divinas ( $\tau \hat{\omega} \nu \quad \theta \epsilon i \omega \nu \dot{\alpha} \nu \alpha \gamma \nu \omega \dot{\sigma} \sigma \iota)$ con intención fiel y agradable a Dios, llama y golpea a lo escondido de ellas, y te abrirá aquel portero de quien dijo Jesús: "A este le abre el portero" (Jn 10,3). Y al aplicarte en la lectura divina $(\theta \in \dot{i} \alpha \underline{\alpha} \dot{\alpha} \alpha \gamma \nu \omega \dot{\omega} \sigma \in \mathrm{L}=$ lectio divina), busca con fe inconmovible en Dios el sentido de las letras divinas, escondido a muchos. Pero no te contentes con golpear y buscar, pues necesaria es de todo punto la oración pidiendo la inteligencia de lo divino. Exhortándonos a ella el Salvador, no solo dijo: "Llamad y se os abrirá, buscad y encontraréis", sino también: "Pedid y se os dará" (Mt 7,7; Lc 11,9)» ${ }^{19}$.

Como se puede apreciar, en su origen, la expresión latina lectio divina invoca distintos elementos, si bien se sitúa siempre en relación a las Escrituras

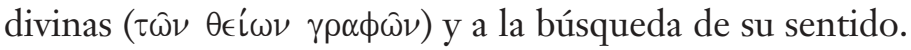

El sentido original del término lectio se encuentra en relación con el concepto de lectura en la antigüedad ${ }^{20}$. En efecto, hoy día tendemos a trasladar al pasado nuestra concepción actual de la lectura, entendida como un acto individual al alcance de todos. Nada más lejos de la realidad: en la antigüedad,

${ }^{18}$ Sobre la posible fecha de la carta, la teoría más seguida es la que la sitúa después del 238, tal vez en el 240, cuando Gregorio está a punto o ha regresado ya a su patria: cfr. MAROTTA, E., Gregorio il Taumaturgo, Discorso a Origene. Con il testo della Lettera di Origene a Gregorio, Roma: Città Nuova Editrice, 1983, 34-37.

19 Orígenes, Carta a Gregorio el Taumaturgo, 4, traducción propia realizada sobre la base de D. Ruiz Bueno en apéndice a Orígenes, Contra Celso, Madrid: BAC, 1967, 616-618. Para una edición crítica completa, cfr. CROUZEL, H., Remerciement à Origène suivi de La lettre d'Origène à Grégoire («Sources Chrétiennes», 148), Paris: Editions du Cerf, 1969, 186-195.

20 Cfr. Maroto, D. de P., «La lectio divina», 434-435; y LeCLERCQ, J., El amor a las letras y el deseo de Dios. Introducción a los autores monásticos de la Edad Media, Salamanca: Sígueme, 2009, 30-31. 
leer era algo reservado para una minoría. No solo porque apenas unos pocos sabían leer y eran capaces de entender lo que estaba escrito, sino también porque el libro era un tesoro de inestimable valor, al alcance de muy pocas fortunas.

Asimismo, leer tenía una connotación de acto público, pues lo normal era leer en voz alta. Por tanto, también incluía oír. En la Biblia tenemos muchos ejemplos de ello: se lee públicamente la Ley a oídos de todo el pueblo (Ex 24,7; Dt 31,11; Jos 8,34) o ante el rey Josías cuando se encuentra en el Templo el rollo de la Ley (2 R 22,10); Baruc lee en el Templo las palabras del Señor escritas al dictado de Jeremías (Jr 36); o, también en el Nuevo Testamento, Jesús lee a Isaías en la sinagoga de Nazaret $(\operatorname{Lc} 4,16)$ y Felipe se entera de lo que estaba leyendo el eunuco porque pasó «a su lado y oyó que leía al profeta Isaías» $(\text { Hch 8,30 })^{21}$.

Este es el significado principal en las formas hebrea y griega, correspondientes al verbo leer. Así, en hebreo, el verbo equivalente a leer es קרז. Su significado principal es el de «gritar», «clamar», «vocear», «proclamar», «pregonar»; solo como tercera acepción significa «leer», especificando, además, que «se leía en voz alta ${ }^{22}$. Algo similar sucedía con el verbo $\alpha \nu \alpha \gamma \iota \nu \omega ́ \sigma \kappa \omega^{23}$.

Finalmente, leer tenía muchas veces como objetivo la instrucción de quienes no habían podido desarrollar esa capacidad. Solo mediante la escucha atenta llegaban a aprender lo que se proclamaba, sobre todo, si se trataba de la lectura de la Sagrada Escritura en la Iglesia. Probablemente eso influyó a la hora de traducir alguna vez lectio por «estudio», en lugar de por «lectura», que sería lo más habitual ${ }^{24}$.

Por tanto, se quedaría corto quien tradujera de manera literal «lectura divina $\gg^{25}$. Lo cierto es que, aunque el modo más habitual de referirse a ella en español sigue siendo mediante la fórmula latina, se ha conseguido introducir algunas acertadas traducciones: lectura orante, lectura creyente, lectura de

${ }^{21}$ Todavía en el s. IV seguirá siendo algo desacostumbrado la lectura privada en voz baja. Recuérdese la reacción de sorpresa de san Agustín al contemplar a san Ambrosio leyendo las Escrituras sin pronunciar las palabras ni mover la lengua: cfr. Confesiones VI,3,3.

${ }^{22}$ Cfr. Alonso SchöKel, L., Diccionario biblico de hebreo-español, Madrid: Trotta, 1994, 668-669.

${ }^{23}$ Cfr. Danker, F. W. (ed.), A Greek-English lexicon of the New Testament and other early Christian literature, Chicago: University of Chicago Press, 2000, 60.

${ }^{24}$ Por ejemplo, en la versión inglesa de la colección Ante-Nicene Fathers (en sus sucesivas ediciones, ya sea la de A. Roberts y J. Donaldson, como la de A. Cleveland Coxe) se interpreta lectura como estudio: «divino estudio».

${ }_{25}$ Cfr. Bianchi, E., Orar la palabra, 43. 
Dios, Biblia orada y vivida, Palabra rezada, escucha orante, orar la Palabra o escuela de la Palabra.

Por otra parte, el adjetivo divina hace referencia a algo perteneciente o relativo a la divinidad o a lo que es propio de Dios. El problema surge al asociar este término -más vinculado a la trascendencia- a una acción propiamente humana como es leer, puesto que cabría entender entonces la lectio como algo que «supera el nivel humano y se sitúa en el campo inalcanzable de la trascendencia» ${ }^{26}$. Para solucionar esta aparente tensión entre ambos términos se han buscado otras explicaciones.

La primera es que divina se refiere, principalmente, al objeto de la lectio, que no es otro que las cosas de Dios ( $\tau \alpha \theta \in \hat{\imath} \alpha$ ), o mejor, las cosas escritas de Dios, es decir, el contenido de la Biblia; en definitiva, la Palabra de Dios. Precisamente porque el contenido es percibido y presentado como Palabra de Dios, puede considerarse divina ${ }^{27}$. Es más, teniendo en cuenta el sentido analógico de la Palabra de Dios (cfr. Verbum Domini, 7), el objeto de la $L D$ sería Dios mismo. Así lo expresan algunos estudiosos cuando se refieren a que es preciso no solo oír a Dios cuando leemos -tal como afirmaron de muchos modos los Padres ${ }^{28}$ - sino también «leer a Dios» ${ }^{29}$. En efecto, leer la Escritura nos pone en contacto directo con Dios, algo que no sucede con ningún otro libro. Así lo expresaba bellamente san Gregorio Magno cuando recomendaba la lectura asidua de la Escritura:

«Aprende a conocer el corazón de Dios en las palabras de Dios» ${ }^{30}$.

Aunque el objeto propio y primordial de la $L D$ lo constituye la Sagrada Escritura, también se incluyeron desde el inicio como parte de la lectio los textos patrísticos, puesto que se consideraban unidos a ella. San Benito recomendaba a sus monjes la lectura de los Padres en cuanto que nos indican el camino recto hacia Dios y nos recuerdan las normas dadas para la vida del hombre

${ }^{26}$ VANNI, U., «Exégesis científica y lectio divina», 22.

$27 \ll$ El contacto directo que la lectio tiene con la Palabra portadora de trascendencia hace que esa lectio sea llamada ella misma divina»: VANNI, U., «Exégesis científica», 23.

${ }^{28}$ Por ejemplo, san Jerónimo ( $«$ Cuando oras, hablas a tu Esposo [Cristo], cuando lees él te habla a ti»: Carta 22.25 a Eustochium) y san Agustín («Tu oración es una locución con Dios, cuando lees, te habla Dios; cuando oras, tú hablas a Dios», Enarratio in Psalmis, 85,7).

29 Cfr. Colombás, G. M., La lectura de Dios. Aproximación a la «Lectio divina», $2^{\mathrm{a}}$ ed., Zamora: Monte Casino, 1982, 33-34.

30 Gregorio Magno, Ep. 4,31. La carta iba dirigida al médico Teodoro. En ella Gregorio establecía la célebre comparación de la Biblia como una carta de Dios a los hombres. 
que se contienen en el Antiguo y el Nuevo Testamento ${ }^{31}$. Sin embargo, poco a poco se prefirió dejar los comentarios patrísticos para la segunda etapa de la lectio: la meditatio ${ }^{32}$. De ahí que los textos de los Padres se suelan considerar como el objeto secundario de la lectio ${ }^{33}$.

Podría decirse que la lectio es divina, finalmente, en tres sentidos más. Por una parte, por la actitud de quien se acerca a ella, esto es, con disposición creyente, como Moisés ante la visión de la zarza (Ex 3), consciente de que se está ante la revelación de Dios. Por otro lado, por su finalidad, es decir, con deseo de que la Palabra se encarne en la propia vida procurando que se dé, a la vez, un verdadero encuentro con Cristo $^{34}$. $\mathrm{Y}$, en tercer lugar, divina se entiende también en sentido subjetivo, es decir, como una

«lectura hecha con Dios, corazón a corazón, con los ojos de la Esposa, en la intimidad de un diálogo de amor» ${ }^{35}$.

En conclusión, según Orígenes, la $L D$ consiste en aplicarse (buscar con perseverancia el sentido) a la lectura (instructiva y procurando memorizar; pero también acompañada y dirigida hacia la oración) de la Sagrada Escritura (las cosas o escritos divinos, la Palabra de Dios, Jesucristo). No en vano, se ha afirmado que en esta carta se hallan los rasgos básicos y fundamentales de la lectio: «dedicación a la Biblia, estudio del texto, intimidad con Cristo y actitud orante» ${ }^{36}$.

\subsection{Un poco de historia ${ }^{37}$}

La $L D$, entendida como un ejercicio ordenado con tiempos bien establecidos no se comienza a practicar hasta época monástica, principalmente con san Benito (ca 480-547). Con todo, hasta Guigo II el Cartujo († 1188), su principal sistematizador, no se podrá hablar todavía de una práctica acabadamente regulada en todas sus etapas.

31 Cfr. RB 73,2-6.

32 Hoy también se sigue aprovechando el tesoro de los Padres de la Iglesia para la $L D$ : cfr. FRATERntTà MONASTICA Di MONTECROCE, Sono Io chi ti parlo: La Lectio divina con i Padri della Chiesa, Roma: Città Nuova, 2008.

33 Cfr. Colombás, G. M., La lectura de Dios, 105-113.

${ }^{34}$ Cfr. Maroto, D. de P., «La lectio divina», 435.

35 Olivera, B., «La tradición de la lectio divina», Cuadernos Monásticos 57 (1981) 180.

${ }^{36}$ Calduch, N., Saboreando la Palabra, 19-20; y Martín FernándeZ-Gallardo, A. M., «Lectio divina. Consideraciones a partir de la Carta de Orígenes a Gregorio Taumaturgo», en Dichosos los que escuchan, 119-134.

37 Para una extensa síntesis, cfr. MASINI, M., La lectio divina, 7-39. 
Ya se ha visto cómo la expresión $L D$ nace con Orígenes. Pero sus inicios van más allá de la época patrística y se remontan al incipiente cristianismo ${ }^{38}$. Ya en el Nuevo Testamento se puede hablar de una cierta $L D$ practicada por el mismo Jesús, en la sinagoga de Nazaret (Lc 4,16-21) y con los discípulos de Emaús (Lc 24,13-35). Asimismo, también en el judaísmo se daba una lectio en sentido amplio, es decir una lectura espiritual (devota o a lo divino) y actualizante de los textos mediante la cual se buscaba entender su sentido y meditar en su conteni$\mathrm{do}^{39}$. De hecho, en las recomendaciones de los rabinos para leer la Escritura ya se hallaban presentes, en cierto modo, tres de las principales etapas de la lectio: leer, meditar, $\operatorname{orar}^{40}$. Este método de lectura fue heredado por el cristianismo, que desarrolló, especialmente desde san Pablo, la lectura alegórica o tipológica (Agar y Sara en Gal 4,21-31; la tradición del éxodo en 1 Cor 10,1-4) ${ }^{41}$.

Ahora bien, fue en el ámbito de los Padres del desierto y del monacato primitivo donde la $L D$ floreció y adquirió una forma más concreta. Entre los Padres del desierto puede mencionarse a san Antonio Abad (ca 270-356), considerado como el iniciador en el cristianismo de la vida eremítica o, al menos, como el primero en marcharse a vivir para siempre al desierto, decisión tomada tras escuchar la respuesta de Jesús al joven rico: «anda, vende todo lo que tienes y dáselo a los pobres, y tendrás un tesoro en el cielo. Luego, ven y sígueme» (Mc 10,21). Junto a otros como Evagrio Póntico (ca 346-399), hay que destacar a Pacomio (ca † 346), que sería el primero en crear una comunidad de monjes: fundó el primer monasterio y puso las bases de lo que poco después sería la regla de san Benito. Todos tienen en común la importancia que otorgaban a la lectura y al estudio de la Sagrada Escritura en su vida eremítica, pues era muy frecuente que acudieran a la Biblia para resolver las dudas de quienes venían a pedir consejo al desierto ${ }^{42}$.

${ }^{38}$ Sobre cómo se leía e interpretaba la Escritura en los tiempos del Antiguo y Nuevo Testamento, cfr. MASINI, M., La lectio divina, 241-286.

39 Un método de actualización de la Escritura muy empleado fue el derás en sus diversas clases: cfr. MUÑoz León, D., Derás. Los caminos y sentidos de la Palabra Divina en la Escritura, Burgos: CSIC, 1987.

${ }^{40}$ Cfr. Bianchi, E., Orar la Palabra, 66. Calduch, N., Saboreando la Palabra, 15.

41 Sobre las técnicas de interpretación de los textos bíblicos en la época de los Padres en relación con la $L D$, cfr. MASINI, M., La lectio divina, 287-307. Cfr. también la síntesis de BARRADO, P., «La Biblia orada y vivida: Lectio divina», Cauriensia 6 (2011) 359-369.

42 En los dichos o apotegmas de los Padres del desierto -textos que se fueron recolectando a lo largo de los ss. IV-V- se recogen valiosos testimonios sobre el amor por la Escritura de estos maestros espirituales: «en todo lo que hagas, busca siempre la aprobación de las Sagradas Escrituras», es lo que se recomienda en el primero de los dichos para agradar a Dios: cfr. Apotegmas de los Padres del desierto, Madrid: BAC, 2017, 7. 
Lo que se comenzó a practicar en el desierto se consolidó con la fundación de los monasterios ${ }^{43}$. Allí la lectio pasaría a ser una de las ocupaciones fundamentales diarias del monje. Se trataba de una lectura más personalizada que comunitaria, que se podía hacer tanto en la celebración de la Eucaristía como en el rezo del Oficio Divino ${ }^{44}$.

Juan Casiano (ca 360-435) da testimonio de la importancia de la lectio en la vida del monje:

«El monje se entrega asiduamente a la lectio (...) Es este el camino más corto para encontrar a Dios. La meditatio de un solo versículo de la Biblia permite cruzar todas las fronteras de lo visible. En muy breves palabras se encierran todos los sentimientos que puede engendrar la oración (...) Debes dedicarte con todo empeño a la sacra lectio hasta que la meditatio asidua haya impregnado tu mente y te haya formado, por decirlo así, a su imagen (...). Para eso debemos aprender cuidadosamente de memoria los libros de las Escrituras y repetirlos de memoria» ${ }^{45}$.

La $L D$ acabó convirtiéndose en una praxis habitual característica, aunque no exclusiva, de la orden benedictina al ser incluida de modo explícito en la $R e-$ gla de san Benito (ca 480-547) ${ }^{46}$. En efecto, preocupado por evitar a sus monjes la ociosidad -a la que consideraba como «enemiga del alma»-, san Benito establece las horas del día que cada uno ha de dedicar a sus principales ocupaciones: el trabajo y la lectura divina. Ambas tareas formarán parte de la jornada monástica habitual: tres cuartas partes del día se corresponden al trabajo y la otra parte, a la lectio ${ }^{47}$. De ahí la célebre fórmula Ora et labora que resume la vida de los monjes benedictinos, un lema que algunos autores consideran que

${ }^{43}$ Sobre los orígenes de la $L D$ y la profundización lograda por los primeros monjes hasta san Jerónimo, véase el antiguo estudio de GORCE, D., La Lectio divina dès origines du cénobitisme à saint Benoist et Cassiodore; I. Saint férôme et la Lecture sacrée dans le milieu ascétique romain, Wépion-surMeuse (Belgique)-Paris: Á. Picard, 1925, 2 vols.

${ }^{44}$ Cfr. MAROTO, D. de P., «La lectio divina», 436.

45 Casiano, Colaciones, I,10; X,2; XIV,10 (texto tomado de Contreras Molina, F., Leer la Biblia como Palabra de Dios. Claves teológico-pastorales de la lectio divina en la Iglesia, Estella: Verbo Divino, 2007, 37).

${ }^{46}$ Ahí aparece en su expresión latina: «por eso han de ocuparse los hermanos a unas horas en el trabajo manual, y a otras, en la lectura divina (in lectione divina) $\gg:$ Regla 48,1 (cfr. Madrid: BAC, 1979, 147). Lógicamente la $L D$ también es muy común entre los cistercienses (basta ver cómo entre los especialistas de la $L D$ se encuentra el monje cisterciense A. M. Martín FernándezGallardo) y otras órdenes monásticas.

47 La duración varía un poco en función de los tiempos litúrgicos y de los días del año, pero en principio se dedicaban tres horas a la lectio: cfr. VOGÜE, A. DE, La regla de san Benito: comentario doctrinal y espiritual, Zamora: Monte Casino, 1985, 314. 
habría que completar, añadiendo lege ${ }^{48} \mathrm{y}$ meditare, pues la lectio incluye no solo la oración sino también la acción de meditar lo leído a lo largo del día ${ }^{49}$.

En cualquier caso, la lectio fue poco a poco quedando como algo reservado para los monjes, como un ejercicio típicamente monástico. No en vano se suele considerar a los monjes como los profesionales de la $L D$. Aunque el proceso se completará más adelante, ya san Juan Crisóstomo (ca 347-407) atestigua que existía esa opinión entre la gente de su tiempo:

«Yo no soy monje -me contestará alguno-, sino que tengo mujer e hijos y he de cuidar mi casa. Pues justamente lo que lo ha echado todo a perder es que pensáis que la lección [lectura] de las divinas Escrituras conviene solo a los monjes, cuando a vosotros os es más necesaria que a ellos. A los que se revuelven en medio del mundo, a los que día tras día reciben heridas, a esos más que a nadie son necesarias las medicinas ${ }^{50}$.

Llama la atención que, a pesar de que el origen de la expresión se encuentre en Orígenes, la práctica de la $L D$ acabara asentándose más en el ámbito de los Padres de Occidente ${ }^{51}$. Aparte de los Padres de esa tradición que ya se han mencionado -san Jerónimo, san Agustín y san Gregorio Magnopuede destacarse también a san Ambrosio, el primero en quien aparece la expresión latina $^{52}$ y quien la introdujo en Occidente ${ }^{53}$, y a san Isidoro de Sevi$\mathrm{lla}^{54}$. En todos ellos se aprecia el convencimiento de que Dios hablaba en la Escritura y seguía hablando al lector creyente. De estas ideas se alimentaron los maestros espirituales de la época medieval ${ }^{55}$.

${ }^{48}$ Orar y leer constituyen, desde antiguo, como dos tiempos del diálogo con Dios: cfr. COLOMBás, G. M., La lectura de Dios, 14-15.

49 Cfr. VoGÜE, A. DE, La regla de san Benito, 314-315.

${ }^{50}$ Homilías sobre el Evangelio de Mateo, 2,5-6: Obras completas, I, Madrid: BAC, 1955, 36-37.

${ }^{51}$ Cfr. Covolo, E. DAL, «Theia anagnosis / Lectio divina: Origene, Ambrogio, Agostino», en KACZMAREK, S. y otros (eds.), Origeniana decima. Origen as writer, Leuven: Peeters, 2011, 727-732.

52 Cfr. Masini, M., La lectio divina, 10. San Ambrosio (ca 340-397) será quien recoja el testigo de la exégesis alegórico espiritual de Orígenes y la traslade a Occidente. Suyas son las famosas palabras asumidas por la $D V$ 25: «a Él hablamos cuando oramos, y a Él oímos cuando leemos las palabras divinas»: De officiis ministrorum, I, 20, 88.

53 Cfr. Benedicto XVI, Catequesis sobre Orígenes (2 de mayo de 2007).

${ }^{54}$ San Isidoro († 636) escribe: «cuando oramos, somos nosotros los que hablamos con Dios; mas cuando leemos, es Dios quien habla con nosotros» (Sentencias, libro III, 8). Esta expresión tiene su raíz en san Cipriano de Cartago: Sit tibi vel oratio assidua vel lectio: nunc cum Deo loquere, nunc Deus tecum (Ep. 1.15).

55 En los siglos XII y XIII se aprecia ya una clara diferencia entre la lectio monástica, la cual tiende hacia la meditatio y la oratio, y se orienta al saber; y la lectio escolástica, que tiende hacia la quaestio y la disputatio, y está orientada al gustar: cfr. LECLERCQ, J., El amor a las letras, 101. 
Entre todos los monjes que se dedicaron a la $L D$ durante la Edad Media ${ }^{56}$ cabe destacar a Guigo II el Cartujo ${ }^{57}$. A él se le atribuye el mérito de sistematizar una práctica espiritual que, aunque ya se vivía por aquel entonces en determinados ambientes, todavía no estaba asentada en todas sus etapas. De hecho, puede considerarse su Carta al hermano Gervasio sobre la vida contemplativa como la Carta Magna de la $L D^{58}$. En ella, Guigo concibe la lectio como el camino espiritual que conduce al monje a la unión con Dios. Inspirándose en el pasaje bíblico del sueño de Jacob (Gn 28,12-13), emplea la tradicional imagen de la escalera como símbolo del ascenso del alma a $\operatorname{Dios}^{59}$ :

\section{«Esta es la Escala de los monjes, por la que se sube de la tierra al cielo» ${ }^{60}$.}

De ahí que también reciba este escrito el nombre de Scala claustralium o de Scala paradisi. Esa escalera está compuesta de diversos peldaños, no aislados sino concatenados, que «se preceden unos a otros no solo temporalmente, sino también causalmente ${ }^{61}$. Cada peldaño corresponde a una fase del método -o un modo de oración- y sugiere la imagen del ascenso progresivo del alma a Dios. Son cuatro: lectio, meditatio, oratio, contemplatio. Para explicar su carácter escalonado y la conexión entre cada peldaño Guigo emplea, entre otras, la imagen de la comida:

«La lectura investiga la dulzura de la vida bienaventurada, la meditación la encuentra, la oración la pide y la contemplación la saborea» ${ }^{62}$.

\footnotetext{
${ }^{56}$ No se puede dejar de mencionar entre ellos a san Bernardo de Claraval († 1153) y a Hugo de san Víctor († 1141).

${ }^{57}$ Fue el noveno prior de la Gran Cartuja, entre los años 1174 y 1180: cfr. GRANADO, C., «Guigo II, sobre la vida contemplativa (Escala de los monjes). Introducción, traducción y notas», Proyección 46 (1999) 291-304.

58 Es tal la importancia que se atribuye a esta carta que muchos autores la incluyen como apéndice en sus estudios sobre la LD: cfr. BiAnCHI, E., Orar la Palabra, 117-148; ZEVINI, G., La lectio divina en la comunidad cristiana: espiritualidad, método, praxis, Estella: Verbo Divino, 2005, 149170; y Calduch, N., Saboreando la Palabra, 83-100. Para un estudio completo de la carta, cfr. MarTín FernándeZ-Gallardo, A. M., La Scala claustralium de Guigo II el Cartujo: experiencia y método de la lectio divina, Zamora: Monte Casino, 1994. Este autor subraya que en la Scala se considera la $L D$ como «una síntesis de espiritualidad cristiana» (201).

59 Cfr. Granado, C., «Guigo II», 293, notas 6 y 7.

${ }^{60}$ Scala I, 293 (cito la traducción española recogida en C. Granado).

${ }^{61}$ Ibid., XI, 94.

${ }^{62}$ Ibid., II, 84.
} 
«La lectura sirve a la boca un manjar sólido, la meditación lo mastica y lo tritura, la oración le saca el sabor y la contemplación es la dulzura misma que alegra y conforta» ${ }^{63}$.

Desde esta época en adelante la lectura de la Palabra de Dios quedará relegada al ámbito monástico e irá siendo «sustituida por otras prácticas de carácter más intelectual o devocional, introspectivo y psicológico» ${ }^{64}$. Comenzará así, ya al final de la Edad Media, el periodo de «exilio» ${ }^{65} \mathrm{o}$ de «eclipse de la Palabra ${ }^{66}$ que desembocará en la crisis protestante del s. XVI. El largo exilio de la Palabra durará hasta el s. XX, momento en el que, como ya se ha visto, despertará de su letargo gracias, entre otros factores, al proceso de vuelta a las fuentes que culminó con el Concilio Vaticano II. La $L D$ regresó entonces para quedarse como patrimonio común de todos los fieles.

\subsection{Hacia una definición de la lectio divina}

En la antigua tradición monástica la $L D$ no se consideraba esencialmente como un método. Era, en todo caso, la oración de los monjes por antonomasia. Con ella se buscaba una lectura más experiencial que intelectual de la Escritura: había que vivirla, no solo leerla. Lo que se buscaba, en definitiva, era tener una experiencia de Dios, un encuentro místico con Él ${ }^{67}$.

Hoy día, en cambio, se entiende la $L D$ como un modo de rezar que toma como base la Sagrada Escritura siguiendo una metodología determinada ${ }^{68}$. Ahora bien, la $L D$ es más que un mero método de oración (que, por otra parte, es muy variable en cuanto al número de pasos). Es mejor entenderla como un «itinerario espiritual en etapas» ${ }^{69}$, como un camino para llegar a $\ll$ ser amigos de Dios» ${ }^{70}$, tal como sucede en el camino de Emaús (Lc 24,13-35) o en el

${ }^{63}$ Ibid., II, 84-85.

${ }^{64}$ Calduch, N., Saboreando la Palabra, 18. Entre estos métodos se encuentran el de san Ignacio o el de la devotio moderna: cfr. MAsINI, M., La lectio divina, 20-21.

${ }^{65}$ Cfr. Bianchi, E., Orar la Palabra, 21.

${ }^{66}$ Masini, M., La lectio divina, 14.

${ }^{67}$ Dreuille entiende la $L D$ como una pedagogía que presenta el desafío de hacernos pasar «de la lectura de un texto al encuentro de una persona» (Lectio divina, 21).

${ }^{68} \mathrm{El}$ aspecto metódico viene a veces subrayado ya desde el mismo título de algunas obras: ZEVINI, G., La lectio divina: silenzio, parola, comunità: metodo ecclesiale ed orante per leggere le Scritture, Brescia: Queriniana, 2018.

${ }^{69}$ BeNEDICTO XVI, Mensaje para la XXI fornada Mundial de la fuventud, 22 de febrero de 2006.

${ }^{70}$ Avellaneda Rutz, P., Unción y banquete: encuentros con la belleza de Dios. Lectio divina: formación $y$ praxis, Madrid: BAC, 2016, 3-10. 
de Gaza (Hch 8,26-40) ${ }^{71}$. Por eso, junto a términos como «peldaños» o «momentos», también se emplean otros vocablos que hacen referencia a la acción de caminar: «pasos» o «etapas».

En consecuencia, siguiendo con la imagen del camino, la $L D$ es una «actividad compleja y progresiva $\gg^{72}$, que requiere esfuerzo. No en vano se equiparaba al trabajo manual en la Regla de san Benito. Tal vez por eso haya sido tan celebrada la definición de la $L D$ propuesta por el cardenal Martini:

«el ejercicio ordenado de la escucha personal de la Palabra» ${ }^{73}$.

Hay que precisar que no se refiere tanto a un ejercicio de «inteligencia discursiva» ni a un mero ejercicio ascético, sino a un «ejercicio orientado a la conversión interior» ${ }^{74}$. La $L D$ no es tampoco «ni una lectura privada de la Biblia (...) ni una meditación, en el sentido usual del término» ${ }^{75}$. No se trata de una «lectura estrictamente ligada a la investigación exegética» ${ }^{76}$, ni mucho menos de un «pasatiempo espiritual» o una «recreación piadosa» ${ }^{77}$.

La finalidad de la $L D$ es bien distinta. Puesto que es, ante todo, un «ejercicio contemplativo» ${ }^{78}$, debe «conducir a la oración, a la contemplación» ${ }^{79}$. Por eso, cabría reducir los cuatro fines propuestos para la $L D$ (teológico, cristológico, eclesial y antropológico ${ }^{80}$ a uno solo: la unión con Dios. Un antiguo apotegma de los Padres del desierto, recogido por Zevini al inicio de su libro ${ }^{81}$, lo pone bien de manifiesto:

Un joven acudió a ver a un anciano ermitaño que dedicaba todo su tiempo a contemplar y a rezar con la Biblia. Tan admirado quedó el jo-

\footnotetext{
${ }^{71}$ Cfr. Dreulle, C. DE, Lectio divina, 21. Otro clásico ejemplo de $L D$ en la misma Biblia es el momento en que Esdras lee al pueblo «el libro de la Ley de Dios con claridad, explicando el sentido, para instruir con la lectura» (Neh 8,8).

72 ZEVINI, G., La lectio divina, 34.

73 Cfr. Martini, C. M., Un pueblo en Camino, Bogotá: Paulinas, 1986, 13; y también en Al alba te buscaré. La escuela de la oración, Estella: Verbo Divino, 1991, 52. Calduch (Saboreando la Palabra, 21-25) desarrolla su explicación de la $L D$ a partir de esta definición.

${ }_{75}^{74}$ Bianchi, E., Orar la Palabra (introducción de F. R. de Pascual), 14.

${ }^{75}$ ZEVINI, G., La lectio divina, 33-34.

${ }^{76}$ Gargano, I., La Lectio divina. Introducción a la «Lectio divina», Santafé de Bogotá: Paulinas, 1992, 5.

77 Colombás, G. M., La lectura de Dios, 65.

78 Bianchi, E., Orar la Palabra, 17.

79 Gargano, I., La Lectio divina, 5. Podría también definirse como «una lenta oración contemplativa de las Escrituras que nos conduce a la unión con Dios» (C. VALTERS, 1).

${ }^{80}$ Cfr. Zevini, G., La lectio divina, 39.

${ }^{81}$ Cfr. ZevinI, G., La lectio divina, 8-9.
} 
ven que le pidió, hasta en dos ocasiones, que le admitiera como discípulo suyo, pues deseaba aprender a orar como él. El anciano no se lo permitió porque, cuando le preguntaba por qué deseaba orar con la Biblia, no le convencían sus respuestas. Por tercera vez acudió el joven a ver al ermitaño y esta vez su contestación fue: «Quiero orar con la Biblia para hacer la experiencia de Dios». Al fin el viejo ermitaño, conmovido, le dejó permanecer como discípulo suyo.

Esta misma finalidad se expresa también en la Verbum Domini:

«[La $L D]$ es verdaderamente "capaz de abrir al fiel no solo el tesoro de la Palabra de Dios sino también de crear el encuentro con Cristo, Palabra divina y viviente" ${ }^{82}$.

Se han formulado muchas definiciones de la $L D$. Todas ellas ponen en relación, en mayor o menor medida, una serie de elementos: Sagrada Escritura (escuchada y acogida en la Iglesia) ${ }^{83}$, oración (personal y comunitaria), vida (cristiana renovada) y unión con Dios (encuentro con la persona de Cristo) ${ }^{84}$. Veamos alguna de ellas:

«La $L D$ es una lectura, individual o comunitaria, de un pasaje más o menos largo de la Escritura acogida como Palabra de Dios, y que se desarrolla bajo la moción del Espíritu en meditación, oración y contemplación ${ }^{85}$.

«... la lectura individual o comunitaria de un pasaje de la Escritura acogida como Palabra de Dios» ${ }^{86}$.

«... la lectura de una página bíblica, realizada a la luz del Espíritu Santo, para que la Palabra se convierta en oración y transforme nuestra vida» ${ }^{87}$.

«Leer, escuchar, retener, profundizar, vivir la Palabra de Dios contenida en la Escritura, sumergirse en ella con fe y amor: en esto consiste, esencialmente, la $L D{ }^{88}$.

${ }^{82}$ Verbum Domini, n. 87, donde se recoge una cita del mensaje final del Sínodo.

${ }^{83}$ Masini (La lectio divina, 151-202), dedica un buen espacio de su libro a situar la Palabra de Dios (Revelación y Escritura) como presupuesto de la $L D$.

${ }^{84}$ Cfr. Zevin, G., La lectio divina, 20-23.

${ }^{85}$ La interpretación de la Biblia en la Iglesia, 1993, n. 44: EB (BAC, 2010), n. 1535.

${ }^{86}$ BARRADO, P., «La Biblia orada», 357.

${ }^{87}$ ZevinI, G., La lectio divina, 36.

${ }^{88}$ Colombás, G. M., La lectura de Dios, 40. 
A ello habría que añadir, finalmente, el carácter sacramental de la lectio ${ }^{89}$. Ya la Verbum Domini proponía la $L D$ como un

«encuentro con la Palabra de Dios a través de los textos bíblicos, un encuentro destinado a preparar, madurar y desarrollar la escucha que tiene lugar en la liturgia ${ }^{90}$.

Esto quiere decir que «toda $L D$ personal debe encontrar en la liturgia de la Palabra la razón última de ser» ${ }^{91}$. Así, igual que la adoración eucarística fuera de la Misa tiene su origen y su fin en la celebración eucarística y se ordena a ella, de modo análogo la $L D$ tiene su fuente, prepara y personaliza la celebración litúrgica. En cierto modo también completa lo que sucede en la liturgia de la Iglesia, pues mientras allí habla Dios al pueblo, en la $L D$ hace resonar su Palabra más personalmente en cada uno:

«Lo que en la liturgia es un diálogo con el pueblo debe transformarse diálogo íntimo y personal en la $L D \gg^{92}$.

Más aún, se considera que «la celebración litúrgica es el modelo de la $L D \gg^{93}$, puesto que es en la liturgia de la Iglesia donde aprendemos a escrutar el sentido profundo de las Sagradas Escrituras.

Llegados al final de este apartado, es el momento de proponer mi propia definición:

La $L D$ es una lectura orante, eclesial y ordenada de la Sagrada Escritura que lleva al encuentro personal con Cristo, a saborear su Palabra $\mathrm{y}$ a dejar que transforme la propia vida.

\section{EL ITINERARIO DE LA LECTIO DIVINA}

Para la práctica de la $L D$ se requieren una serie de disposiciones previas ${ }^{94}$. Entre las más generales se encuentran las teológicas (fe en la presencia de Je-

${ }^{89}$ Este rasgo ha sido especialmente subrayado por H. Raguer. Según él, son tres los rasgos distintivos de la $L D$ que la diferencian de la lectura espiritual: «tener la Biblia por objeto, el carácter sacramental y su estrecha relación con la oración»: «Introducción a la lectio divina», 366.

90 Ibid., 402.

91 BiANCHI, E., Orar la Palabra, 57.

92 BIANCHI, E., Orar la Palabra, 58.

93 Gargano, I., La Lectio divina, 37.

${ }^{94}$ En la Carta de Orígenes ya se señalaban las condiciones previas para la $L D$ : «fe y búsqueda de Dios»: MasinI, M., La lectio divina, 9. 
sús en la Escritura, en la unidad entre Antiguo y Nuevo Testamento, etc.) y las espirituales (humildad, pureza de corazón, etc.) ${ }^{95}$. Entre las más específicas, están las condiciones que rodean al momento mismo de la $L D$ : lugar y tiempo escogidos, postura, respiración, etc. Se trata de prepararse del mejor modo posible para facilitar, con el recogimiento y la concentración (tarea difícil para el hombre moderno de hoy), una profunda escucha de la Palabra ${ }^{96}$.

En cuanto al número de pasos en los que desarrollar la $L D$ hoy, no hay un consenso generalizado. Sí se está de acuerdo en seguir las cuatro etapas básicas establecidas por Guigo II, adaptándolas un poco a la situación del orante actual: lectio, meditatio, oratio, contemplatio ${ }^{97}$.

Tampoco es fácil distinguir dónde empieza y dónde acaba cada una. La razón es que cada peldaño no es más que una de las etapas del proceso natural de lectura y asimilación de la Palabra de Dios, en el que unas se entrelazan con las otras; por eso no cabe automatización alguna. Lo expresa bien un pasaje de la Scala Claustralium de Guigo en que realiza una paráfrasis de Mt 7,7 («Pedid y se os dará, buscad y encontraréis, llamad y se os abrirá»):

«Buscad leyendo y encontraréis meditando, llamad orando y se os abrirá contemplando ${ }^{98}$.

a) Lectio («Buscad leyendo»): «įQué dice el texto biblico en sí mismo?»99

«La lectura consiste en el estudio diligente de las Escrituras con atención de la mente» ${ }^{100}$.

95 Podrían entenderse como pre-disposciones: cfr. ZevinI, G., La lectio divina, 38-39.

96 Cfr. Paintner, C. V. y WYNKoOP, L., Lectio divina: contemplative awakening and awareness, New York: Paulist Press, 2008, 162-171. Ahí se enumeran las condiciones para conseguir una profunda escucha.

97 Algunos autores incluyen también la collatio, que se da solo en caso en caso de lectura comunitaria: Masini la sitúa entre la meditatio y la oratio (La lectio divina, 423-425); Zevini, en cambio, tras la contemplatio (79-87). Se trata de las aportaciones de los participantes tras su reflexión.

98 Este dicho se atribuyó durante mucho tiempo a Guigo. Así aparece en el Catecismo de la Iglesia Católica, n. 2654. También lo recogerá san Juan de la Cruz en uno de sus dichos de luz y de amor concretamente el n. 157. En realidad, parece no pertenecer a la Carta original. Granado no recoge esta frase en su edición (ni Calduch, pues le sigue en su texto). Tampoco Bianchi, y eso que su explicación de la $L D$ se centra en esta frase (68-107). En cambio, sí aparece en la edición de Fernández Gallardo, 35, donde explica en nota que se trata de una variante que no aparece recogida en la edición crítica porque solo se encuentra en dos manuscritos del s. XV.

99 Verbum Domini, n. 87.

100 Scala, II, 293. 
Se trata de leer atentamente el texto bíblico para buscar su significado auténtico. Aunque no es preciso hacer un ejercicio completo de exégesis, sin embargo, habrá que recurrir a ella para hacer una lectura «inteligente» y captar el sentido literal del texto, que es el fundamento de todos los demás ${ }^{101}$ :

«Los antiguos, refiriéndose al Verbo encarnado, afirmaban que la carne es el fundamento de la salvación; en la Escritura la visibilidad y el significado de la letra, que nosotros, alcanzamos gracias a los exegetas, es el fundamento del conocimiento ulterior, que se obtiene por la relación personal que se establece con la Escritura misma» ${ }^{102}$.

Así pues, es preciso leer, subrayar y releer el texto las veces que sean necesarias, para reconocer los elementos más relevantes: delimitación del texto y estructura, contextos, géneros literarios, personajes, términos y símbolos empleados, etc. Serán de gran ayuda los comentarios a la Sagrada Escritura, concordancias, diccionarios bíblicos y otro material auxiliar.

En esta fase se invita a «leer a Dios con el Espíritu de Dios» ${ }^{103}$, a escuchar en profundidad la voz de Dios en la Escritura y a gustarla. Aquí entra en juego la ruminatio, es decir, la acción de rumiar, masticar y asimilar la Palabra, que conlleva también la memorización del texto o de una parte de él. Esta operación introduce ya a la meditatio ${ }^{104}$.

En definitiva, la lectio se entiende como una lectura atenta y pausada que es, a la vez, escucha personal e íntima, de corazón a corazón, asidua, desinteresada, dialogada, rumiada y acogida en la fe de Iglesia ${ }^{105}$.

b) Meditatio («Encontraréis meditando»): «¿Qué nos dice el texto biblico a nosotros?» ${ }^{106}$

«La meditación consiste en la actividad de la mente que, con ayuda de su propia razón, estudia e investiga el conocimiento de la secreta ver$\mathrm{dad} \gg{ }^{107}$.

101 Cfr. Balaguer, V., «El sentido literal y el sentido espiritual de la Sagrada Escritura», ScrTh 36 (2004) 509-563.

102 Gargano, I., La Lectio divina, 6.

103 Olivera, B., «La tradición de la lectio divina», 180.

104 Cfr. Bianchi E., Orar la Palabra, 91-94.

105 Cfr. Gargano, I., La Lectio divina, 11-21; y Colombás, G. M., La lectura de Dios, 34-70 y 116-117.

106 Verbum Domini, n. 87.

107 Guigo II, Scala, II, 293. 
La acción de meditar, en ámbito monástico, incluía no solo la repetición, -con la boca o con el corazón- para aprender el texto de memoria. También adoptó su significado más profano, el cual hace alusión al ejercicio de pensar, de prepararse y de desear realizar la acción que se está meditando ${ }^{108}$. Asimismo, para el monje la lectio se prolongaba a lo largo del día con la meditatio de lo que se ha leído, especialmente mientras se estaba trabajando.

En el itinerario de la $L D$, la meditación es una especie de «parada interior» ${ }^{109}$ en la que el alma se dirige a Dios intentando comprender lo que quiere decirle hoy con su Palabra. La atención pasa ahora de las palabras a los sentimientos o actitudes de Dios hacia el hombre ${ }^{110}$. Es el momento de gustar y saborear la Palabra leída, de encontrar lo que se buscaba con la lectura, de llevar a la mente y al corazón el contenido más profundo del texto. Pero, más que nada, es la fase del requerimiento y de la interpelación, donde se trae al presente el texto y se aplica a las propias circunstancias de la vida. Es el momento de dejarse cuestionar, ya sea de modo personal como comunitariamente, por la Palabra leída y de comprometerse a realizar lo que Dios pide. Esto enlaza con el siguiente paso.

c) Oratio («Llamad orando»): «iQué decimos nosotros al Señor como respuesta a su Palabra?» ${ }^{111}$

«La oración es la orientación piadosa del corazón hacia Dios para apartar los males o alcanzar bienes» ${ }^{112}$.

Hasta ahora Dios ha dirigido su Palabra al orante; ahora es uno mismo el que dirige sus palabras a Dios ${ }^{113}$. Tras meditar y gustar la bondad del Señor (cfr. Sal 34[33],9) y conocer lo que Dios pide a cada uno en ese texto, llega el momento de responderle ${ }^{114}$. La respuesta más apropiada es la oración, que brota en sus cuatro expresiones principales: alabanza, acción de gracias, petición de perdón e intercesión. Pero, sobre todo, surge en forma de diálogo personal con Dios. Un diálogo que toma como punto de partida la confrontación

\footnotetext{
108 Cfr. LeCLeRCQ, J., El amor a las letras, 32-34.

109 Benedicto XVI, Mensaje JMJ 2006.

${ }^{110}$ Cfr. Martini, C. M., Un pueblo en Camino, 16.

111 Verbum Domini, n. 87.

112 Guigo II, Scala, II, 293.

113 Cfr. MasinI, M., La lectio divina, 397.

${ }^{114}$ Cfr. ZevinI, G., La lectio divina, 73-74.
} 
llevada a cabo en la etapa anterior, entre los sentimientos de Dios expresados en el texto sagrado y la realidad de la propia vida. Un diálogo esperanzado que va acompañado de una actitud de fe, de disponibilidad, de humildad sencilla frente a la Palabra de Dios ${ }^{115}$.

d) Contemplatio («...y se os abrirá contemplando»): «iQué conversión de la mente, del corazón y de la vida nos pide el Señor?» ${ }^{116}$

«La contemplación consiste en cierta elevación sobre sí misma de la mente que queda suspendida en Dios al saborear los gozos de la dulzura eterna» ${ }^{117}$.

Es la última fase y el resultado de la $L D^{118}$. También es la más difícil de explicar porque la contemplación la suscita en nosotros el Espíritu Santo y es algo muy personal. Por eso, si en las anteriores etapas el orante estaba activo e incluso podía emplear ciertas técnicas o material auxiliar, ahora es el momento de permanecer pasivo, en silencio, privado de todo, a solas con Dios, en actitud de admiración, sabiéndose contemplado por Él. Es el momento de la experiencia consoladora de Dios. Y ahí toda la iniciativa es divina. También en lo que respecta a los tiempos. De todas formas, aunque a la contemplación no se llega por un esfuerzo continuado de la voluntad, es más fácil que venga después de una prolongada oración de la Palabra ${ }^{119}$.

En definitiva, todos los pasos anteriores han de ayudar a salir de uno mismo para poder entrar en el misterio de Dios ${ }^{120}$, de modo similar a como Moisés entraba en la Tienda del Encuentro (Ex 33,7-11) ${ }^{121}$. De ahí que se haya comparado la $L D$ a un gran éxodo que cada uno ha de realizar, imagen del largo peregrinaje que dura desde el Paraíso hasta el «cielo nuevo y la tierra nueva». En ese viaje hay una nube de fuego -como la del Éxodo de Egipto- o una estrella -como la de los Magos de Oriente- que guía al alma: es la Biblia ${ }^{122}$,

\footnotetext{
Cfr. ZevinI, G., La lectio divina, 23.

Verbum Domini, n. 87.

Gutgo II, Scala, II, 293.

118 Cfr. Bianchi E., Orar la Palabra, 98-107.

119 Cfr. Zevini, G., La lectio divina, 76-79.

120 Cfr. Martini, C. M., Un pueblo en Camino, 17.

121 La Biblia en ese sentido no es un libro para leer sino donde habitar: cfr. ColOMBás, G. M., La lectura de Dios, 117.

122 Cfr. Avellaneda Ruiz, P., Unción y banquete, XIX-XX.
} 
leída, meditada, orada y contemplada en la $L D$. La contemplación puede entenderse entonces como el momento culminante del regreso al Paraíso:

«Cuando tomamos con fe las Sagradas Escrituras en nuestras manos, y las leemos con la Iglesia, el hombre vuelve a pasear con Dios en el paraíso» ${ }^{123}$.

e) La mayor parte de los autores ha terminado por añadir un paso más: la actio $^{124}$. Es el momento en que la Palabra escuchada y acogida se incorpora a la propia vida para poder mirar el mundo a la luz de la Escritura y actuar en consecuencia ${ }^{125}$ :

«la $L D$ no termina su proceso hasta que no se llega a la acción (actio), que mueve la vida del creyente a convertirse en don para los demás por la caridad» ${ }^{126}$ (Verbum Domini, n. 87).

Llegados al final de este itinerario por la $L D$, ahora ya solo queda seguir el consejo de aquella inocente voz que escuchó el santo obispo de Hipona una tarde de agosto del año 386 en un jardín de Milán: «iToma y lee»! ${ }^{127}$

\section{UN EJEMPLO: LOS DisCíPUlos DE EMAÚS}

Puesto que se pueden encontrar fácilmente ejemplos desarrollados de $L D^{128}$, se proponen a continuación, de modo esquemático, unas sencillas pautas que pretenden servir de ayuda para la $L D$ personal. Se ha escogido la escena de los discípulos de Emaús (Lc 24,13-35), además de por la cercanía de la Pascua, porque constituye un buen ejemplo de lo que es en sí misma la $L D^{129}$.

123 SAN Ambrosio, Epistula 49.

${ }^{124}$ Masini prefiere llamarla operatio, refiriéndose con ello a la capacidad operativa de la Palabra que transforma a quien la lee y le lleva a dar testimonio a los demás (cfr. La lectio divina, 407-411).

125 Para Gargano, el «punto de llegada de la $L D$ se llama evangelización» (La Lectio divina, 61).

126 Verbum Domini, n. 87.

127 Confesiones VIII,12,29.

${ }^{128}$ Han desarrollado ejemplos prácticos la mayor parte de los autores mencionados: Bianchi, Zevini, Gargano, Masini, Calduch, Martini, Barrado, etc. Asimismo, han proliferado las páginas web donde pueden encontrarse ejemplos de $L D$. Son también útiles las guías didácticas que se han ido publicando para facilitar la $L D$. Entre ellas se pueden destacar: MEsTERs, C., EQUIPO Bíblico CRB y LA CASA DE LA Biblia, Lectura orante de la Biblia, Estella: Verbo Divino, 1997; y García Garcimartín, R., La Lectio Divina: Un itinerario antiguo con posibilidades nuevas, Estella: Verbo Divino, 2011.

129 He tomado de las obras de Barrado («La Biblia orada», 372-374) y Martini (Al alba te buscaré, 57-73) algunas ideas para mi propuesta. 
Antes de comenzar a leer, conviene hacer la señal de la Cruz e invocar la ayuda del Espíritu Santo: «iVen, ob Santo Espiritu!, llena los corazones de tus fieles y enciende en ellos el fuego de tu amor».

1) Lectio: Leer pausadamente el pasaje (puede hacerlo un lector primero y después se pueden dejar unos 10/15 minutos de relectura personal para detenerse en el texto y fijarse en algunos detalles) ${ }^{130}$.

Buscar información sobre el contexto histórico y literario del texto leído. Puede bastar una introducción de alguna Biblia comentada. En este caso, puede mirarse la Biblia anotada por los profesores de la Universidad de Navarra:

San Lucas escribe la primera parte de su obra entre los años 80 y 90. Dirige su mensaje a una comunidad procedente en su mayoría del paganismo. Funto a la misericordia de fesús y la centralidad de ferusalén, una de las características de su evangelio es acrecentar la fe de esos primeros cristianos. El pasaje funciona como una especie de puente entre el anuncio de la resurrección y las apariciones a los Once; de hecho, complementa la escena anterior en la que Jesús se aparece primero a las santas mujeres.

Dividir el texto en escenas o actos y establecer su momento central. Cada escena podría corresponder a los principales momentos de la $L D$ :

- Escena 1 (13-15): Marcha desesperanzada de los dos discípulos a Emaús y conversación entre ellos. Podría reflejar la situación anterior a la Lectio.

- Escena 2 (15-24): Jesús aparece de improviso y se pone a caminar con ellos, escuchando su versión de los acontecimientos. Correspondería ya a la lectio (qué es lo que ha ocurrido).

- Escena 3 (25-27): Explicación que Jesús da a los dos discípulos de los acontecimientos a la luz de las Escrituras, todavía en el camino hasta la llegada a la aldea y la petición a Jesús de que se quede. Meditatio (comprensión y aplicación personal de la Escritura, ardor de corazón) y Oratio ( Quédate junto a nosotros»).

- Escena 4 (28-32): Ya en casa, se reúnen juntos a la mesa. Reconocen a Jesús al partir el pan. Momento central. Contemplatio (intimidad con

${ }^{130}$ En el resto de etapas cada uno empleará el tiempo que considere oportuno hasta completar unos 25/30 minutos. 
Jesús en la Eucaristía, dejarse abrir los ojos para reconocer su presencia).

- Escena 5 (33-35): Vuelta inmediata a Jerusalén con la misión de dar testimonio de la Buena Nueva: Ha resucitado. Jesús vive. Actio (llevar el Evangelio a los demás una vez alimentados y transformados por la Palabra).

Hacerse preguntas competentes sobre el relato (qué, cómo, cuándo, por qué, dónde):

- ¿Cuándo se da esta aparición? ¿Tiene alguna relación este pasaje con las otras apariciones transmitidas por san Lucas?

- ¿Quiénes son los personajes? ¿Cómo se expresa en el relato su actitud al inicio y al final?

- ¿Por qué los discípulos volvían de Jerusalén? ¿A dónde se dirigían? ¿Se sabe algo de Emaús?

- ¿Por qué al principio no reconocen a Jesús y sí lo hacen al final?

- ¿Qué acciones suceden desde la situación inicial a la final? ¿Qué es lo que provoca la transformación radical de los discípulos?

- ¿Qué puede decirse del caminante, del camino y del caminar? ¿Qué sentido tienen otros símbolos como la fracción del pan, el abrir los ojos o que se haga de noche?

2) Meditatio: Detenerse personalmente en algún pasaje concreto o en algún símbolo que haya llamado más la atención. Identificarse con los personajes, por ejemplo, con el discípulo del que no sabemos el nombre (¿a propósito?). El hecho de que Emaús no haya sido identificada con certeza nos lleva a pensar que Emaús representa el mundo, nuestro propio mundo. $\mathrm{Y}$ en ese camino del mundo encontramos como compañero a Jesús:

- ¿Cómo y a dónde me pide caminar Jesús? ¿Cómo se hace presente en mi vida Jesús Resucitado?

- ¿Pasa su presencia desapercibida por culpa de mis conversaciones superficiales con mis compañeros de camino? ¿O es, por el contrario, una presencia entusiasmante, consoladora, vivificante, esperanzada y comprometida?

- ¿Acudo a la Sagrada Escritura y a la Eucaristía para encontrarme con Él? ¿Qué camino tomo ante mis desánimos? 
3) Oratio: Entrar en diálogo con Jesús tras escuchar y meditar su Palabra.

- Entablamos una conversación con Jesús muy distinta a la que llevábamos antes de encontrarnos con Él y le planteamos todas nuestras inquietudes.

- Le pedimos al Señor, como los discípulos de Emaús que se quede con nosotros y que nos gustaría quedarnos siempre con Él, acompañándole físicamente junto al Sagrario y, cuando no podamos, haciéndole compañía con nuestro pensamiento: «Quédate junto a nosotros que la tarde está cayendo».

- Pedimos perdón al Resucitado por las veces que preferimos caminar solos, con los ojos cerrados y estando en nuestras cosas, ignorando que Él camina con nosotros.

- Le pedimos a Jesús resucitado que arda nuestro corazón en su compañía, que abra nuestros ojos ante nuestra falta de fe y que podamos ir a anunciar la alegría de nuestro encuentro con Él a nuestros amigos.

- Damos gracias a Jesús por partir hoy también el Pan para nosotros, por entregarse Él mismo como Pan, por darse como alimento que nos da fuerzas para recorrer nuestro camino.

- Alabamos a nuestro Dios por regalarnos también su Palabra en la Escritura.

4) Contemplatio: Las palabras resultan pobres y se pasa a la contemplación agradecida de Jesús en la Eucaristía.

- Contemplamos también sus divinas llagas que sirvieron para identificarse ante los Apóstoles y que nos hablan de hasta qué extremo llega el Amor de Dios: «dentro de tus llagas escóndeme».

- Sentimos la presencia de Jesús, que nos anima y reconforta; la presencia del Buen Pastor que da la vida por sus ovejas, que carga con nosotros y nos conduce a buenos pastos; la presencia del Caminante que nos guía y precede, y que es a la vez Camino; la presencia del Pan que nos da la vida y nos fortalece.

5) Actio: Compromiso de identificarse con el Divino Caminante para llevar a los demás la alegría del evangelio, igual que hizo Él con los discípulos de Emaús: con su misma actitud luminosa y esperanzada, y teniendo las Escrituras y la Eucaristía como centro. 


\section{Bibliografía}

Avellaneda Ruiz, P., Unción y banquete: encuentros con la belleza de Dios. Lectio divina: formación y praxis, Madrid: BAC, 2016.

Balaguer, V., «La Constitución Dogmática Dei Verbum y los estudios bíblicos en el siglo XX», Anuario de Historia de la Iglesia 10 (2001) 239-251.

Balaguer, V., «El sentido literal y el sentido espiritual de la Sagrada Escritura», Scripta Theologica 36 (2004) 509-563.

Barrado, P., «La Biblia orada y vivida: Lectio divina», Cauriensia 6 (2011) 355 377.

Benedicto XVI, Exhortación Apostólica Postsinodal Verbum Domini, Madrid: San Pablo, 2010.

Bianchi, E., Orar la Palabra, Burgos: Monasterio de las Huelgas, 1994 (Torino: Gribaudi, 1974).

Calduch-Benages, N., Saboreando la Palabra. Sobre la lectura orante o creyente (lectio divina), Estella: Verbo Divino, 2012.

Calduch-Benages, N., «El Sínodo de Obispos sobre la Palabra de Dios: balance y perspectivas», Isidorianum 35 (2009) 317-338.

Colombás, G. M., La lectura de Dios. Aproximación a la «Lectio divina», $2^{a}$ ed., Zamora: Monte Casino, 1982.

Concilio Vaticano II, «Constitución Dogmática Dei Verbum sobre la divina revelación Dei Verbum», en Concilio Vaticano II: Constituciones. Decretos. Declaraciones. Legislación posconciliar, $8^{\mathrm{a}}$ ed., Madrid: Editorial Católica, 1975.

Contreras Molina, F., Leer la Biblia como Palabra de Dios. Claves teológico-pastorales de la lectio divina en la Iglesia, Estella: Verbo Divino, 2007.

Covolo, E. DAL, «Theia anagnosis / Lectio divina: Origene, Ambrogio, Agostino», en KaczmareK, S. y otros (eds.), Origeniana decima. Origen as writer, Leuven: Peeters, 2011, 727-732.

DreullLe, C. DE, Lectio divina: un camino para orar la Palabra de Dios, Estella: Verbo Divino («Cuadernos Bíblicos», 164), 2014.

Dreyfus, F., «Exégése en Sorbonne, exégése en Église», Revue Biblique 82 (1975) 321-359.

Fraternità monastica di Montecroce, Sono Io chi ti parlo: La Lectio divina con i Padri della Chiesa, Roma: Città Nuova, 2008.

García Garcimartín, R., La Lectio Divina: Un itinerario antiguo con posibilidades nuevas, Estella: Verbo Divino, 2011. 
García Serrano, A. y Sánchez Navarro, L. (eds.), Dichosos los que escuchan la Palabra. Exégesis biblica y lectio divina, Madrid: Universidad San Dámaso, 2012.

GARGANO, I., Iniziazione alla «lectio divina». Indicazioni metodologiche con I'ezemplificazione di alcuni branni presi dal Vangelo secondo Matteo, Bologna: EDB, 1993.

Gargano, I., La Lectio divina. Introducción a la «Lectio divina», Santafé de Bogotá: Paulinas, 1992.

GRANADO, C., «Guigo II, sobre la vida contemplativa (Escala de los monjes). Introducción, traducción y notas», Proyección 46 (1999) 291-304.

LECLERCQ, J., El amor a las letras y el deseo de Dios. Introducción a los autores monásticos de la Edad Media, Salamanca: Sígueme, 2009.

Magrassi, M., Bibblia e preghiera. Lectio divina, Milano: Àncora, 1973.

MANICARDI, E., «Verbum Domini: perspectivas teológicas actuales», Scripta Theologica 43 (2011) 393-416.

Maroto, D. de P., «La Lectio divina. Praxis histórica y pastoral», Salmanticensis 49 (2002) 433-462.

Marotta, E., Gregorio il Taumaturgo, Discorso a Origene. Con il testo della Lettera di Origene a Gregorio, Roma: Città Nuova Editrice, 1983.

Martín Fernández-Gallardo, A. M., La lectio divina ayer y boy. Principios y desarrollo bistórico, Estella: Verbo Divino, 2012.

Martín Fernández-Gallardo, A. M., La Scala claustralium de Guigo II el Cartujo: experiencia y método de la lectio divina, Zamora: Monte Casino, 1994.

Martín Fernández-Gallardo, A. M., «Lectio divina. Consideraciones a partir de la Carta de Orígenes a Gregorio Taumaturgo», en GARCía SErrano, A. y Sánchez Navarro, L. (eds.), Dichosos los que escuchan la Palabra, 119-134.

Martini, C. M., Un pueblo en Camino, Bogotá: Ediciones Paulinas, 1986.

MARTini, C. M., Al alba te buscaré. La escuela de la oración, Estella: Verbo Divino, 1991.

MASINI, M., La lectio divina: teología, espiritualidad, método, Madrid: BAC, 2001.

Mesters, C., Equipo bíblico CRB y La CASA DE la Biblia, Lectura orante de la Biblia, Estella: Verbo Divino, 1997.

Muñoz León, D., Derás. Los caminos y sentidos de la Palabra Divina en la Escritura, Burgos: CSIC, 1987.

Olivera, B., «La tradición de la lectio divina», Cuadernos Monásticos 57 (1981) 179-203. 
PAINTNER, C. V. y WYNKoOP, L., Lectio divina: contemplative awakening and awareness, New York: Paulist Press, 2008.

Pennington, B., Lectio Divina: Renewing the Ancient Practice of Praying the Scriptures, New York: Crossroad Classic, 1998.

Pontificia Comisión Bíblica, La Interpretación de la Biblia en la vida de la Iglesia (15 de abril de 1993).

Raguer, H., «Introducción a la Lectio Divina», Cuestiones Teológicas 32 (2005) $365-412$.

RATZINGER, J. y otros, Escritura e interpretación. Los fundamentos de la interpretación biblica, Madrid: Palabra, 2003.

VANNI, U., «Exégesis científica y lectio divina: dos realidades inseparables», en García Serrano, A. y Sánchez Navarro, L. (eds.), Dichosos los que escuchan la Palabra, 15-32.

VoGÜE, A. DE, La regla de san Benito: comentario doctrinal y espiritual, Zamora: Monte Casino, 1985.

ZEVINI, G., La lectio divina en la comunidad cristiana: espiritualidad, método, praxis, Estella: Verbo Divino, 2005.

ZevinI, G., La lectio divina: silenzio, parola, comunità: metodo ecclesiale ed orante per leggere le Scritture, Brescia: Queriniana, 2018. 
